\title{
Penerapan Sistem Fuzzy Tsukamoto Dalam Memperkirakan Hasil Produksi Padi
}

\author{
Lena Sapura ${ }^{1}$, Agiffuddinsyah Sinaga ${ }^{2}$, Firdaus Siahaan ${ }^{3}$ \\ ${ }^{1,2,3}$ Mahasiswa STIKOM Tunas Bangsa, Pematangsiantar - Indonesia \\ Jln. Sudirman Blok A No. 1-3 Pematangsiantar, Sumatera Utara \\ Ilainasakura13@gmail.com, 2agifsinaga21@gmail.com, ${ }^{3}$ daussiahaan99@gmail.com
}

\begin{abstract}
Plantations are all activities that commercialize certain plants on the soil and / or other growing media in suitable ecosystems; process and market the goods and services produced by these plants, with the help of science and technology, capital and management to create prosperity for plantation businesses and the community. In ordinary or more dominant plantations, rice fields with sufficient yields and even processing with a fairly short period of time, especially in rice. Rice is the main or basic need and source of calories for humans. Factors that affect rice production include land, seeds, weather, and fertilizer, these factors clearly affect the quality and amount of production produced by farmers. The fuzzy logic method applies Tsukamto's fuzzy inference system in estimating rice production with the variables that influence it. The research objective is to estimate how much rice production with the Tsukamoto method of fuzzy inference using AND operations based on land variables, rice seed material, fertilizer, and the amount of production.
\end{abstract}

Keywords: Rice, Total Production, Tsukamoto Method, Operation AND

\begin{abstract}
Abstrak
Perkebunan adalah segala kegiatan yang mengusahakan tanaman tertentu pada tanah dan atau media tumbuh lainnya dalam ekosistem yang sesuai; mengolah da memasarkan barang dan jasa hasil tanaman tersebut, dengan bantuan ilmu pengetahuan dan teknologi, permodalan serta manajemen untuk mewujudkan kesejahteraan bagi pelaku usaha perkebunan dan masyarakat. Dalam perkebunan biasa atau lebih dominan yaitu sawah dengan hasil panen yang cukup bahkan pengolahan dengan jangka waktu yang cukup singkat, terutama pada padi. Padi merupakan kebutuhan utama atau pokok dan sumber kalori bagi manusia. Factor - factor yang mempengaruhi produksi padi antara lain lahan, bibit, cuaca, dan pupuk, factor-faktor ini jelas mempengaruhi kualitas dan jumlah produksiyang dihasilkan oleh petani. Metode logika fuzzy mengaplikasikan sistem inferensi fuzzy Tsukamto dalam memperkirakan produksi padi dengan variabel-variabel yang mempengaruhinya. Tujuan penelitian adalah memperkirakan berapa banyak produksi padi dengan sistem inferensi fuzzy metode Tsukamoto dengan menggunakan operasi AND berdasarkan variabel lahan, bahan bibit padi, pupuk, dan jumlah produksi.
\end{abstract}

Kata Kunci: Padi, Jumlah Produksi, Metode Tsukamoto, Operasi AND

\section{Pendahuluan}

Perusahaan perkebunan adalah suatu perusahaan berbentuk badan usaha/badan hukum yang bergerak dalam kegiatan budidaya tanaman perekebunan diatas lahan yang dikuasai, dengan tujuan ekonomi/komersial dan mendapat izin usaha adri isntansi yang berwewenang dalam pemeberian izin usaha perkebunan. Usaha budidaya tanaman perkebunan diluar bentuk badan usaha, seperti yang diusahakan perorangan tanpa izin usaha atau diusahakan oleh rumah tangga petani tidak termasuk dalam konsep ini dan biasanya disebut usaha perkebuan rayat,dan dalam subjek pelaksaannnya disebutkan dengan petani. 
Dalam pelaksanaannya para petani lebih dominan menanam kebutuhan pokok seperti padi. Padi (Oryza Sativa) merupakan bahan baku pangan pokok yang vital bagi rakyat Indonesia. Menanam padi di sawah dengan kategori milik sendiri sudah mandarah daging bagi kalangan petani, usaha ini bahkan sudah tersebar di seluruh daerah yang ada di Indonesia. Penanaman padi membutuhkan waktu 3 bulan, mulai dari proses penjetoran tanah seperti meratakan lahan dan penyemprotan racun hama seperti racun keong mas dan menunggu sekira 10 hari lalu dilanjutkan dengan penjabutan rumput dan mulai menanam benih bibit padi dan selama 3 bulan waktu pemberian pupuk dilakukan 3 kali pemupukan dengan selang waktu 10 hari sekali. Dan masa penjemuran padi yang sudah menguning membutuhkan waktu yang tergantung dengan cuaca, jika cuaca bagus dengan mataharik terik masa penjemuran hanya membutuhkan waktu 3-5 hari dan jika cuaca buruk membutuhkan waktu kurang lebih 1 minggu selama masa penjemuran.

Pada teori logika fuzzy diketahui konsep sistem fuzzy digunakan dalam proses memprediksi dan secara umum mengandung empat tahapan: fuzzifikasi, pembentukan aturan fuzzy, penalaran sistem inferensi fuzzy, dan defuzzifikasi. Metode inferensi fuzzy yang biasanya digunakan adalah Mamdani, Sugeno, dan Tsukamoto. Tetapi pada studi metode inferensi fuzzy ini yang digunakan adalah metode Tsukamoto. Permasalahan penelitian adalah bagaimana menerapkan sistem inferensi fuzzy metode Tsukamoto dalam menentukan perkiraan hasil dari produksi padi dengan variabel lahan, benih bibit padi, dan pupuk. Penelitian ini bertujuan untuk membuat sistem inferensi fuzzy metode Tsukamoto yang dapat digunakan untuk memperkirakan hasil dari produksi padi.

\section{Metodologi Penelitian}

\subsection{Logika Fuzzy}

Logika merupakan ilmu yang mempelajari secara sistematis kaidah-kaidah penalaran yang absah (valid) [1]. Ada dua jenis logika yang ada pada kehidupan manusia, yaitu logika crisp (tegas) dan logika Fuzzy (samar-samar). Logika tegas hanya memiliki dua buah keadaan pada setiap pernyataan, yaitu true (1) dan false (0). Sedangkan, logika Fuzzy memiliki nilai yang samar-samar diantara 0 dan 1 [1]

\subsection{Metode Tsukamoto}

Fuzzy Inferensi Tsukamoto ini didasarkan pada teori himpunan Fuzzy yang berbentuk IF-THEN untuk mengambil keputusan dalam bentuk nilai tegas dari nilai samar-samar [2]. Fuzzy Inferensi Tsukamoto ini menggunakan fungsi keanggotaan yang berasal dari data yang diinput untuk dapat menentukan nilai tegas [3].

\subsection{Operasi Logika (Operasi himpunan fuzzy)}

Operasi logika adalah operasi yang mengkombinasikan dan memodifikasi 2 atau lebih himpunan fuzzy. Nilai keanggotaan baru hasil operasi dua himpunan disebut firing strength atau $\alpha$ predikat [4], ada 3 operasi dasar yang diciptakan oleh Zadeh :

a) Operator AND, berhubungan dengan operasi intersection pada himpunan, $\alpha$ predikat diperoleh dengan mengambil nilai minimum antar kedua himpunan. $\mu \mathrm{A} \cap \mathrm{B}=\min (\mu \mathrm{A}[\mathrm{X}[, \mu \mathrm{B}[\mathrm{y}])$

b) Operator OR, berhubungan dengan operasi union pada himpunan, $\alpha$ predikat diperoleh dengan mengambil nilai maximum antar kedua himpunan. $\mu \mathrm{AUB}=\max (\mu \mathrm{A}[\mathrm{x}], \mu \mathrm{B}[\mathrm{y}])$

c) Operasi NOT, berhubungan dengan operasi komplemen pada himpunan, $\alpha$ predikat diperoleh dengan mengurangkan nilai keanggotaan elemen pada himpunan dari 1 [5]. 


\subsection{Pengambilan Data}

Dalam pengumpulan data menggunakan metode wawancara langsung pada narasumbernya langsung, seorang petani yang memiliki perkebunan milik sendiri dengan sesi tanya jawab sehingga menghasilkan data-data yang diperlukan.

\section{Hasil dan Pembahasan}

Pada hasil diskusi ini pembentukan fungsi keanggotaan, pembentukan aturan fuzzy, dan menguji data dan metode.

\subsection{Pembentukan Fungsi Keanggotaan}

Tahap pertama, menentukan fungsi keanggotaan. Dari semua data, dalam mendapatkan beberapa masukan fungsi keanggotaan yaitu fungsi lahan, bibit benih padi, dan pupuk.

Tabel 1. Fungsi Anggota

\begin{tabular}{|l|l|l|}
\hline Nama Variabel & Nama Asosiasi Fuzzy & Domain \\
\hline \multirow{2}{*}{ Lahan (ladang) } & Luas & 5 (ra1ntai) \\
\cline { 2 - 3 } & Sempit & 1 (rantai) \\
\hline \multirow{2}{*}{ Benih bibit padi } & Sedikit & $1 \mathrm{~kg}$ \\
\cline { 2 - 3 } & Banyak & $5 \mathrm{~kg}$ \\
\hline Pupuk & Sedikit & $100 \mathrm{~kg}$ \\
\cline { 2 - 3 } & Banyak & $150 \mathrm{~kg}$ \\
\hline
\end{tabular}

Dalam data ini hitungan lahan 1 rantai $=400$ meter $^{2}$ dengan hitungan Panjang $\mathrm{x}$ lebar $=20 \mathrm{~m} \times 20 \mathrm{~m}$. Menurut Petani berdasarkan wawancara langsung dengan lahan 5 rantai akan menghasilkan padi maximum 13 karung padi dengan hitungan 1 karung berisi $75 \mathrm{~kg}$, dan apabila perawatannya berkurang akan menghasilkan minimum 10 karung padi. Dan jika diolah menjadi beras akan menghasilkan setengah dari jumlah padi sebelumnya.

\subsection{Pembentukan Aturan Fuzzy}

Setelah membentuk fungsi keanggotaan, tahap selanjutnya membuat aturan fuzzy, karena ada dua masukan aturan fungsi keanggotaan fuzzy menghasilkan 16 aturan termasuk semua variabel. Metode inferensi fuzzy yang digunakan adalah Tsukamoto dan operasi logika yang digunakan adalah operato AND himpunan, $\alpha$ predikat diperoleh dengan mengambil nilai minimum antar kedua himpunan.

$\mu \mathrm{A} \cap \mathrm{B}=\min (\mu \mathrm{A}[\mathrm{X}[, \mu \mathrm{B}[\mathrm{y}])$.

[RI] Jika lahan sempit dan bibit sedikit dan pupuk sedikit dan produk berkurang. [R2] Jika lahan sempit dan bibit banyak dan pupuk sedikit dan produk berkurang. [R3] Jika lahan sempit dan bibit sedikit dan pupuk banyak dan produk berkurang. [R4] Jika lahan sempit dan bibit banyak dan pupuk banyak dan produk berkurang. [R5] Jika lahan sempit dan bibit sedikit dan pupuk sedikit dan produk bertambah. [R6] Jika lahan sempit dan bibit banyak dan pupuk sedikit dan produk bertambah. [R7]Jika lahan sempit dan dabibit sedikit dan pupuk banyak dan produk bertambah. [R8] Jika lahan sempit dan bibit sedikit dan pupuk banyak dan produk bertambah. [R9] Jika lahan luas dan bibit sedikit dan pupuk sedikit dan produk berkurang. [R10] Jika lahan luas dan bibit banyak dan pupuk sedikit dan produk berkurang. [R11] Jika lahan luas dan bibit sedikit dan pupuk banyak dan produk berkurang. [R12] Jika lahan luas dan bibit banyak dan pupuk banyak dan produk berkurang. [R13] Jika lahan luas dan bibit sedikit dan pupuk sedikit dan produk bertambah. [R14] Jika lahan luas dan bibit banyak dan pupuk sedikit dan produk bertambah. [R15] Jika lahan luas dan bibit sedikit dan pupuk banyak dan produk bertambah. [R16] Jika lahan luas dan bibit banyak dan pupuk banyak dan produk bertambah. 


\subsection{Pengujian}

Pengujian pertama adalah perilaku yang mana data masukannya: $1.400 \mathrm{~m}^{2}=$ lahan, $4 \mathrm{~kg}=$ bibit, dan $120 \mathrm{~kg}=$ pupuk. Derajat keanggotaan setiap variabel pada data masukan

a) Lahan $=1.400 \mathrm{~m}^{2}$

$$
\begin{aligned}
& \text { usempit }\left[1.400 \mathrm{~m}^{2}\right]=\frac{2000 \mathrm{~m}^{2}-1.400 \mathrm{~m}^{2}}{2000 \mathrm{~m}^{2}-400 \mathrm{~m}^{2}}=0,37 \mathrm{~m}^{2} \\
& \text { uluas }\left[1.400 \mathrm{~m}^{2}\right]=\frac{1.400 \mathrm{~m}^{2}-400 \mathrm{~m}^{2}}{2000 \mathrm{~m}^{2}-400 \mathrm{~m}^{2}}=0,62 \mathrm{~m}^{2}
\end{aligned}
$$

b) Bahan baku bibit $=4 \mathrm{~kg}$

$$
\begin{aligned}
& \text { Psedikit }[4 \mathrm{~kg}]=\frac{5 \mathrm{~kg}-4 \mathrm{~kg}}{5 \mathrm{~kg}-1 \mathrm{~kg}}=0,25 \mathrm{~kg} \\
& \mu \text { banyak }[4 \mathrm{~kg}]=\frac{4 \mathrm{~kg}-1 \mathrm{~kg}}{5 \mathrm{~kg}-1 \mathrm{~kg}}=0,75 \mathrm{~kg}
\end{aligned}
$$

c) Pupuk $=120 \mathrm{~kg}$

$$
\begin{aligned}
& \text { Psedikit }[120 \mathrm{~kg}]=\frac{150 \mathrm{~kg}-120 \mathrm{~kg}}{150 \mathrm{~kg}-100 \mathrm{~kg}}=0,6 \mathrm{~kg} \\
& \mu \text { banyak }[4 \mathrm{~kg}]=\frac{120 \mathrm{~kg}-100 \mathrm{~kg}}{150 \mathrm{~kg}-100 \mathrm{~kg}}=0,4 \mathrm{~kg}
\end{aligned}
$$

Kemudian mencari predikat $\alpha$ setiap aturan fuzzy:

[R1] Jika lahan sempit dan bibit sedikit dan pupuk sedikit dan produk berkurang. predikat $1 \alpha=\min (\mu$ sempit(105.4); $\mu$ sedikit(63.9); $\mu$ sedikit(1))

$$
z 1=0,25
$$

$$
=\min (0,37 ; 0,25 ; 0,6)
$$

$\mu$ berkurang $[0,25]=\frac{975 \mathrm{~kg}-x}{975 \mathrm{~kg}-720 \mathrm{~kg}}=911,25 \mathrm{~kg}$

[R5] Jika lahan sempit dan bibit sedikit dan pupuk sedikit dan produk bertambah. predikat5 $\alpha=\min (\mu$ sempit $(105.4)$; $\mu$ sedikit $(63.9)$; $\mu$ sedikit $(1))$

$$
z 1=0,25
$$

$$
\mu \text { bertambah }[0,25]=\frac{x-720 \mathrm{~kg}}{975 \mathrm{~kg}-720 \mathrm{~kg}}=776,25 \mathrm{~kg}
$$

Dengan cara yang sama untuk menghitung dari [R2] sampai [R16] seperti di atas. Kemudian mencari jumlah rata-rata produksi dengan menggunakan hasil predikat $\alpha$, yaitu:

$$
\begin{aligned}
& \mathrm{Z}^{*}=\sum \frac{a 1 \times 1+a 2 \times 2+a 3 \times 3+\ldots \text { anxn }}{a 1+a 2+a 3+\ldots a n} \\
& 0,37 x 803,25+0,25 x 776,25+0,25 x 776,25+0,25 x 918,75+0,6 x 840+0,25 x 918,75 \\
& \mathrm{z}=\sum \frac{+0,4 \times 885+0,25 \times 776,25+0,6 \times 855+0,4 \times 810+0,4 \times 810}{0,25+0,37+0,25+0,37+0,25+0,37+0,25+0,25+0,25+0,6+0,25+} \\
& \mathrm{Z}=\sum \frac{4.351,2885}{5,51}=789,70753 \mathrm{~kg} \\
& 0,4+0,25+0,6+0,4+0,4
\end{aligned}
$$

\section{Kesimpulan}

Berdasarkan hasil dan diskusi, dapat disimpulkan bahwa perhitungan fuzzy dengan menggunakan metode Tsukamoto terhadap semua data dengan studi ini menghasilkan jumlah rata rata produksi yaitu, dan hasil perhitungan sendiri tersebut cukup akurat. Untuk perkembangan selanjutnya, dapat dipelajari kembali dengan menambahkan empat atau lebih variabel yang dapat mengakibatkan kalkulasi perhitungan jumlah produksi lebih akurat dan kita dapat membandingkan masalah ini dengan metode lainnya. 


\section{Daftar Pustaka}

[1] Kaswidjanti Wilis, dkk. 2014. Implementasi Fuzzy Inference System Metode Tsukamoto Pada Pengambilan Keputusan Pemberian Kredit Pemilikan Rumah.Telematika Vol. 10(2) : 1-10.

http://jurnal.upnyk.ac.id/index.php/telematika/article/download/281/243

[2] Murti Tri, dkk. 2015. Sistem Penunjang Keputusan Kelayakan Pemberian Pinjaman Dengan Metode Fuzzy Tsukamoto. Seminar Nasional Inovasi dan Tren (SNIT) : A 252-256.

https://arxiv.org/abs/1506.00091

[3] Rahman Arkham Zahri, dkk. 2012. Fuzzy Inference System Dengan Metode Tsukamoto Sebagai Pemberi Saran Pemilihan Konsentrasi. Seminar Nasional Aplikasi Teknologi Informasi(SNATI).

https://journal.uii.ac.id/Snati/article/view/2903

[4] W Rahmat Wahyu, dkk. 2009. Aplikasi Fuzzy Inference Systen(Fis) Metode Tsukamoto Padasimulasi Traffic Light Menggunakan Java. Seminar Nasional Aplikasi Teknologi Informasi(SNATI) : E 104-107.

[5] Sugumonrong, D. P., Handinata, A., \& Tehja, A. (2019). Prediksi Harga Emas Menggunakan Metode Fuzzy Time Series Model Algoritma Chen. Informatics Engineering Research And Technology Volume 1 NO.1, 48-54. 